\title{
Trend Analizi Yöntemleri Kullanılarak Doğu Anadolu Bölgesi Aylık Yağış Miktarlarının Değerlendirilmesi
}

\author{
Serkan Şenocak ${ }^{1 *}$, Muhammed Fatih Emek ${ }^{2}$ \\ ${ }^{1}$ Atatürk Üniversitesi, Mühendislik Fakültesi, İnşaat Mühendisliği Bölümü, Erzurum, Türkiye (ORCID: 0000-0002-4962-5349) \\ 2 Karayolları 12. Bölge Müdürlüğü, Erzurum, Türkiye (ORCID: 0000-0001-7378-6460)
}

(İlk Geliş Tarihi 1 Kasım 2019 ve Kabul Tarihi 26 Kasım 2019)

(DOI: 10.31590/ejosat.646266)

REFERENCE: Şenocak, S. \& Emek, M.F. (2019). Trend Analizi Yöntemleri Kullanılarak Doğu Anadolu Bölgesi Aylık Yağış Miktarlarının Değerlendirilmesi. Avrupa Bilim ve Teknoloji Dergisi, (17), 807-822.

\section{Özet}

Bu çalışmada, Doğu Anadolu Bölgesi’ne düşen aylık ve yıllık toplam yağışların trend analizinin araştırılması hedeflenmiştir. Bu amaçla, Meteoroloji Genel Müdürlüğü'nün 46 adet yağış gözlem istasyonundan alınan, 1960 ile 2013 y1lları arasında değişen, verilere Run testi ve Pettitt testi uygulanarak homojenlik analizi yapılmıştır. Homojen olduğu belirlenen istasyonlara Mann - Kendall testi ve Spearman'ın Rho testi uygulanarak trend analizi incelenmiş, Sen'in eğim metodu kullanılarak trendlerin eğimi belirlenmiştir.

Aylık toplam yağışların trend analizi değerlendirildiğinde yaz aylarında genellikle yağışların artan yönde eğilimde olduğu, kış aylarında ise azalan yönde eğilimde olduğu görülmüştür. Yazın Haziran ayında bölgede azalan yönde bir eğilim hâkimken, Temmuz ayında yerini artan yönde bir eğilime bırakmaktadır. Kasım ayı olduğunda ise bölgeye düşen aylık toplam yağışlarda tekrardan azalan yönde eğilim hakim olmaktadir.

\section{Evaluation of Monthly Precipitation Amount in Eastern Anatolia Region by Using Trend Analysis Methods}

\begin{abstract}
In this study, the research of trend analysis of total monthly and annual rainfalls fall to East Anatolia Region have been targeted. For this purpose, with applying Run test and Pettitt test to data that is taken from General Directorate of Meteorology's 46 units rainfall observation station, changing from 1960 to 2013, homogeneity analysis was performed. With performing Mann-Kendall test and Spearman's Rho test to station determined as homogeneous trend analysis was examined, with using Sen's slope method trend's slope was determined.

As to assessed monthly total rainfalls trend analysis, it is observed that in the summer months generally rainfalls are increasing direction tendency, in the winter months it is decreasing direction tendency. In summer in June when a decreasing direction tendency is dominated at region, in July it gives place to increasing direction tendency. When it is November, again decreasing direction tendency at monthly total rainfalls to region is dominated.
\end{abstract}

Keywords: East Anatolia Region, Trend Analysis, Mann-Kendall Test, Spearman's Rho Test, Sen Trend Slope Method.

\footnotetext{
* Sorumlu Yazar: Atatürk Üniversitesi, Mühendislik Fakültesi, İnşaat Mühendisliği Bölümü, Erzurum, Türkiye, ORCID: 0000-0002-4962-5349, ssenocak@atauni.edu.tr
} 


\section{Introduction}

Precipitation is the most important component of the complex hydrological cycle with its effect in our daily life. For this reason, precipitation is usually taken as a starting point for understanding the changes in the processes that direct climate. Precipitation data is mostly recorded on land surface and an important element for monitoring the hydrological cycle (Acar and Şenocak 2008).

Long term mean annual rainfall in $631 \mathrm{~mm}$ in Turkey while it was determined to reduce by $15 \%$ in 1999 and $7 \%$ in 2000 . In addition to the decrease in the mean annual rainfall, the deviation in the precipitation regime is also a consideration to be emphasized.

In addition, this decrease in rainfall and the deviation in precipitation regime adversely affect agricultural production. If these conditions continue to cause droughts in the coming years, water - related larger problems may occur in the future (Türkeş 1999, Öztürk 2002). However, the sudden decrease in subtropical zone rainfall started to be effective in the eastern Mediterranean Basin and Turkey from 1970s. Significant decreasing trends in rainfall and droughts have emerged as more pronounced in winter. In addition, the Aegean, Mediterranean, Marmara and Southeastern Anatolia regions were the most affected by the arid conditions in the 20-25 years between the early 1970s and the mid-1990s (Türkeş 1998).

There are several studies conducted on the trend analysis of precipitation, flow and temperature data. Demirci et al. (2009) used Thiessen and Mann-Kendall method for the trend of annual, seasonal and monthly mean, maximum and minimum temperatures over the 32-year period between 1975 and 2006 in Istanbul; The tendency of average, maximum and minimum temperatures was determined.

Demirci et al. (2009) used Thiessen and Mann-Kendall method for the annual, seasonal and monthly data obtained over a 32-year period between 1975 and 2006 in Istanbul. The tendency of average, maximum and minimum temperatures was determined. As a result of this study, in the 32-year period for the province of Istanbul, it was observed that the temperatures increased by $0.83^{\circ} \mathrm{C}$ in annual average temperatures.

Gümüş and Yenigün (2006) investigated the presence and staring point of the trend over the data of 4 current observation stations in the Lower Euphrates Basin using the Mann Kendall method.

Acar and Şenocak (2008) analysed short-term rainfall trends in Turkey's southern province of Adana, which is an important settlement, in time intervals ranging between 5 to 60 minutes. As a result of the study, a significant trend was determined in 5 , 10 , 15 and 30 minute time scales.

Acar and Senocak (2012) estimated trend analysis with the 1, 6, 12, 24-hour time scale in western Turkey using the 50- year annual data from 7 rainfall stations. After the homogeneity analysis of the data obtained from the rainfall stations during the study, trend analysis was performed with Mann - Kendall test and the slope of the trend was determined by Sen's slope method. As a result of this trend analysis study, a significant trend increase was observed in all time scales for İzmir province, whereas for Antakya and Bursa provinces, a significant trend increase was observed in the 12 - hour time scale. At the same time, breaking year was expressed as 1973 and 1974 for rainfall in the west of Turkey.

Çiflik (2012) investigated the trend of the annual rainfall from 49 DSİ (state water affairs) stations located in the Aegean Region during the 44 - year period between 1962-2005. In this trend study, non-parametric Mann, Kendall, Mann Kendall Mertebe Correlation, Sen-T test and Spearman's rho test were used. According to Mann Kendall, Spearman's rho and T test results, decreasing trend was found in 9 stations.

In the study conducted by Şen (2013), the rainfall and temperature data obtained from the 5 stations in Isparta province were evaluated by using nonparametric Men - Kendall and Spearman's rho test methods. Trend baseline years were evaluated using MannKendall Mertebe Correlation test and trends tendency was determined using Sen's trend tendency method and Linear regression method.

In the study conducted by Uçgun (2010), the trend analysis of rainfall, temperature, evaporation and flow data were performed with the data collected from the observation stations in Kizllırmak Basin. In the analysis of the flow data, decreasing trend was observed in 4 stations.

In the study of Büyükyıldız (2004), the trend analysis of the rainfall falling on the Sakarya Basin was examined and at the same time stochastic modeling was performed. In this trend study, Sen's T test, Spearman's rho test, Mann - Kendall test and seasonal Mann Kendall test were used under two headings, monthly average annual bases and monthly change of rainfall of each station.

Partal and Kahya (2006) determined the significance of monthly and annual precipitation data in Turkey using trend analysis. This study adopted non-parametric methods using the Mann - Kendall test and Sen's T-test. A 64 - year data set between 1929 and 1993 was used over 96 stations.

Güventürk (2013) aimed to determine the rainfall trends in the Euphrates, Tigris, Aras and Çoruh basins located in eastern Turkey. In these four basins, the trend analysis was conducted from 15 stations and evaluated for a 40-year period between 1970 and 2010 . As a result of the trend of rainfall, a significant increase was observed in November, December, January and February. In March, April, May and June, there was a slight decrease in large river flows. Seven among 15 selected stations tended to decrease in the number of wet days.

Norrant and Douguédroit (2006) performed trend analysis on monthly, seasonal and yearly time scales of the Mediterranean geography between the years of 1950 and 2000. Mann - Kendall test method was used over the data obtained from 63 stations in the study. 
Mondal et al. (2012) conducted the trend analysis of rainfall in the Orissa River Basin in India. Mann Kendall test and Sen's T Test method were used among nonparametric methods. As a result of the study conducted a 40-year period in the Orissa Basin between 1971 and 2010, it was stated that these trends are not significant despite the determination of both trend slope with increasing and decreasing direction with Mann - Kendall test.

Liu et al. (2012) collected the data from 186 rainfall measurement stations covering the years 1956 to 2000 in the city of Guangdong in southern China and evaluated them using Mann - Kendall test method on monthly, seasonal and annual bases.

Gautam and Acharya (2012) is different from other studies in that study samples in others are evaluated according to the amount of precipitation this study evaluates the trend analysis of flow quantities.

Serrano et al. (1999), conducted trend analysis of the total monthly and annual rainfall in the Iber Peninsula.

In the study conducted by Siddik and Rahman (2014), the data obtained from 15 observation stations in Bangladesh between 19612008 were analyzed by using Mann Kendall test method for maximum, minimum and average temperatures. At the same time, Sen's slope method was used to determine the magnitude of the trend.

In the study conducted by Talaee (2014), Mann - Kendall and Spearman's rho test methods were used to analyse the trend of the data from 7 rainfall measurement stations in the west of Iran between 1969 and 2009.

Raziei et al. (2014) performed trend analysis over the data obtained from the Global Precipitation Climatology Center in Iran for a 50-year period between 1951 and 2009 considering monthly, seasonal and annual rainfall values.

Han et al. (2013) completed a trend analysis over river flows and precipitation trends in the Xiangxi River Basin on monthly, seasonal and annual bases using the Mann - Kendall test and Sen's slope method.

In some recent studies, it has been pointed out that the annual rainfall in the Mediterranean and Aegean Regions, the decrease in the total rainfall in the winter season is strong (Demir et al. 2007, Türkeş et al. 2007).

It may be helpful to know the change in the amount of water over time and use, store and plan more carefully water. For this reason, there is a significant need for statistical methods such as trend analysis (Gümüş and Yenigün 2006). The better the trend analysis of rainfall is, the better to know and determine the future of water. A study covering the Eastern Anatolia Region was conducted in order to determine the past and the future of the rainfall. With this study, it is aimed to determine the trends in the last 50 years on a monthly basis with the monthly rainfall data obtained from the stations within the borders of the Eastern Anatolia Region of the State Meteorological Directorate. In this study, in Eastern Anatolia covering 163,000 km², 21\% of Turkey, non-parametric methods of MannKendall test and were used to determine rainfall trend and to Sen's slope test to determine the trend slope.

\section{Materials and Methods}

\subsection{Study area and Data}

East Anatolia Region is the east of Turkey and roughly of the triangular shape and the most elevated part of the country. The region is bordered by the south faces of the North Anatolian Mountains in the north and the north high skirts of the Taurus Mountains in the south. Regional boundary separating the region from the Interior Anatolia follows the rough water section of the line of the Kizllirmak and Euphrates rivers and with 163,000 square kilometers of surface area, the region constitutes $21 \%$ of the Turkey's surface area, which carries the region to the first place among seven geographic regions.

The main surface characteristics of the region are the folded mountain ranges and the plains and plateaus between them. The average elevation of the major part of the region does not fall below 1500 meters, and more than half of the region's surface area is located at an altitude of 2000-2500 m.

East Anatolia Region is deeply inserted into the continental - originated climatic regions of Asia and surrounded by high mountain ranges from north and south. For this reason, the region is closed to the favourable climatic effects of the Mediterranean and Black Sea. Although it differs within the region, the semi-arid, arid continental climatic characteristics with long, severe and hard winters are dominant in the region. Depending on the altitude, the average annual temperature is between 3 and $13^{\circ} \mathrm{C}$. The most severe winter conditions are experienced especially in the northeastern part of the region. Due to lower humidity content in the region where terrestrial dominance is observed, daily temperature differences are high and evaporation rate is also high in the southern parts. The region is rich in water resources. 


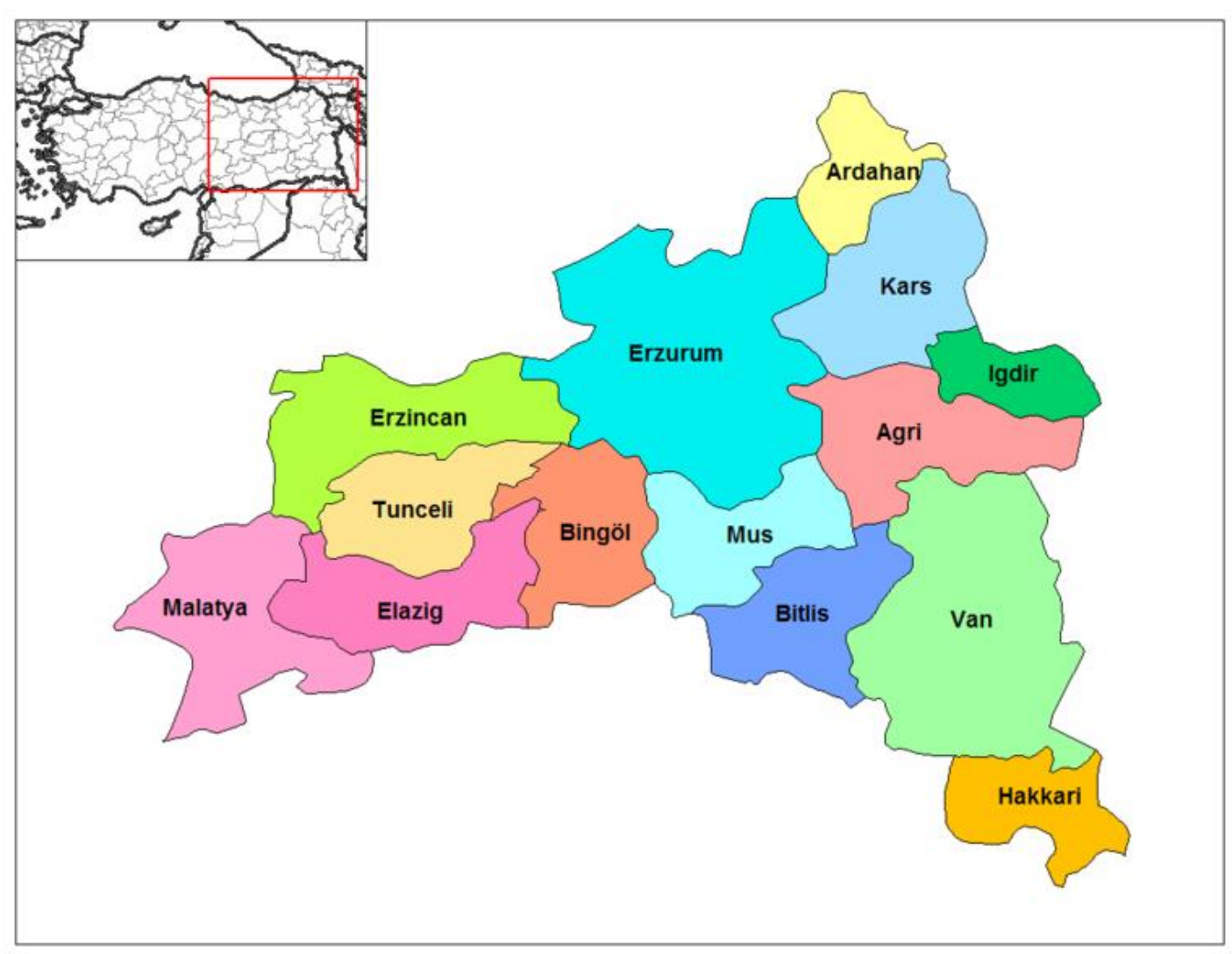

Figure 2.1. Map including provinces in East Anatolia

\subsubsection{Data}

Monthly rainfall data to be used in the study were collected from 46 meteorological rainfall measurement stations of the General Directorate of State Meteorological Affairs (Table 2.1). 
European Journal of Science and Technology

Table 2.1. Rainfall measurement stations considered in the study

\begin{tabular}{|c|c|c|c|c|}
\hline Station & Longitude $\left({ }^{0} \mathbf{E}\right)$ & Latitude $\left({ }^{0} \mathrm{~N}\right)$ & Elevation (m) & Record Duration \\
\hline Ağr1 & 43.05 & 39.72 & 1646 & $1960-2013(54)$ \\
\hline Doğubeyazıt & 44.08 & 39.55 & 1725 & $1963-2009(47)$ \\
\hline Ardahan & 42.70 & 41.10 & 1827 & $1961-2013(53)$ \\
\hline Erzincan & 39.48 & 39.75 & 1216 & $1960-2013(54)$ \\
\hline Tercan & 40.39 & 39.77 & 1429 & $1964-2013(50)$ \\
\hline Erzurum & 41.18 & 39.95 & 1758 & $1960-2008(49)$ \\
\hline Hinıs & 41.69 & 39.36 & 1715 & $1964-2001(48)$ \\
\hline Horasan & 42.17 & 40.03 & 1540 & $1969-2013(45)$ \\
\hline İspir & 40.99 & 40.48 & 1223 & $1965-2011(47)$ \\
\hline Oltu & 41.99 & 40.54 & 1312 & $1966-2013(48)$ \\
\hline Tortum & 41.54 & 40.30 & 1576 & $1963-2013(51)$ \\
\hline Iğdır & 44.05 & 39.92 & 856 & $1960-2013(54)$ \\
\hline Kars & 43.10 & 40.60 & 1777 & $1960-2013(54)$ \\
\hline Arpaçay & 43.32 & 40.84 & 1688 & $1970-2013(44)$ \\
\hline Sarıkamış & 42.59 & 43.32 & 2092 & $1963-2013(51)$ \\
\hline Bingöl & 40.50 & 38.88 & 1177 & $1963-2013(51)$ \\
\hline Genç & 40.55 & 38.73 & 1250 & $1980-2013(34)$ \\
\hline Solhan & 41.05 & 38.95 & 1366 & $1965-2013(49)$ \\
\hline Elazı̆̆ & 39.25 & 38.64 & 989 & $1960-2013(54)$ \\
\hline Ağın & 38.71 & 38.94 & 900 & $1979-2013(35)$ \\
\hline Baskil & 38.83 & 38.57 & 1300 & $1979-2013(35)$ \\
\hline Karakoçan & 40.04 & 38.94 & 1090 & $1980-2013(34)$ \\
\hline Keban & 38.74 & 38.79 & 808 & $1963-2013(51)$ \\
\hline Maden & 39.40 & 38.23 & 1100 & $1980-2010(31)$ \\
\hline Palu & 39.92 & 38.69 & 869 & $1966-2013(48)$ \\
\hline Sivrice & 39.31 & 38.45 & 1240 & $1979-2013(35)$ \\
\hline Malatya & 38.21 & 38.33 & 950 & $1960-2013(54)$ \\
\hline Arapgir & 38.48 & 39.04 & 1211 & $1964-2010(47)$ \\
\hline Doğanşehir & 37.88 & 38.09 & 1223 & $1965-2013(49)$ \\
\hline Tunceli & 39.54 & 39.10 & 981 & $1964-2013(50)$ \\
\hline Çemişgezek & 38.90 & 39.05 & 953 & $1969-2013(45)$ \\
\hline Mazgirt & 39.60 & 39.01 & 1400 & $1982-2013(32)$ \\
\hline Bitlis & 42.16 & 38.47 & 1785 & $1965-2010(46)$ \\
\hline Ahlat & 42.47 & 38.74 & 1730 & $1968-2013(46)$ \\
\hline Tatvan & 42.28 & 38.50 & 1687 & $1965-2013$ (49) \\
\hline Hakkari & 43.73 & 37.57 & 1727 & $1963-2013(51)$ \\
\hline Yüksekova & 44.28 & 37.57 & 1877 & $1969-2011(43)$ \\
\hline Muş & 41.50 & 38.75 & 1322 & $1964-2013(50)$ \\
\hline Malazgirt & 42.53 & 39.13 & 1540 & $1963-2013(51)$ \\
\hline Varto & 41.44 & 39.17 & 1510 & $1977-2010(34)$ \\
\hline Van & 43.34 & 38.46 & 1675 & $1960-2013(54)$ \\
\hline Başkale & 44.01 & 38.04 & 2286 & $1964-2013(50)$ \\
\hline Erciş & 43.33 & 39.01 & 1678 & $1965-2013$ (49) \\
\hline Gevaş & 43.11 & 38.29 & 1694 & $1982-2013(32)$ \\
\hline Özalp & 43.97 & 38.65 & 2000 & $1969-2013(45)$ \\
\hline Muradiye & 43.76 & 38.98 & 1706 & $1964-2013(50)$ \\
\hline
\end{tabular}

Since the data were not homogeneous at a total of 8 rainfall measurement stations of Ahlat, Ardahan, Arpaçay, Hakkari, Kars, Özalp, Malatya and Yüksekova among 46 ones, these were excluded from the study. 


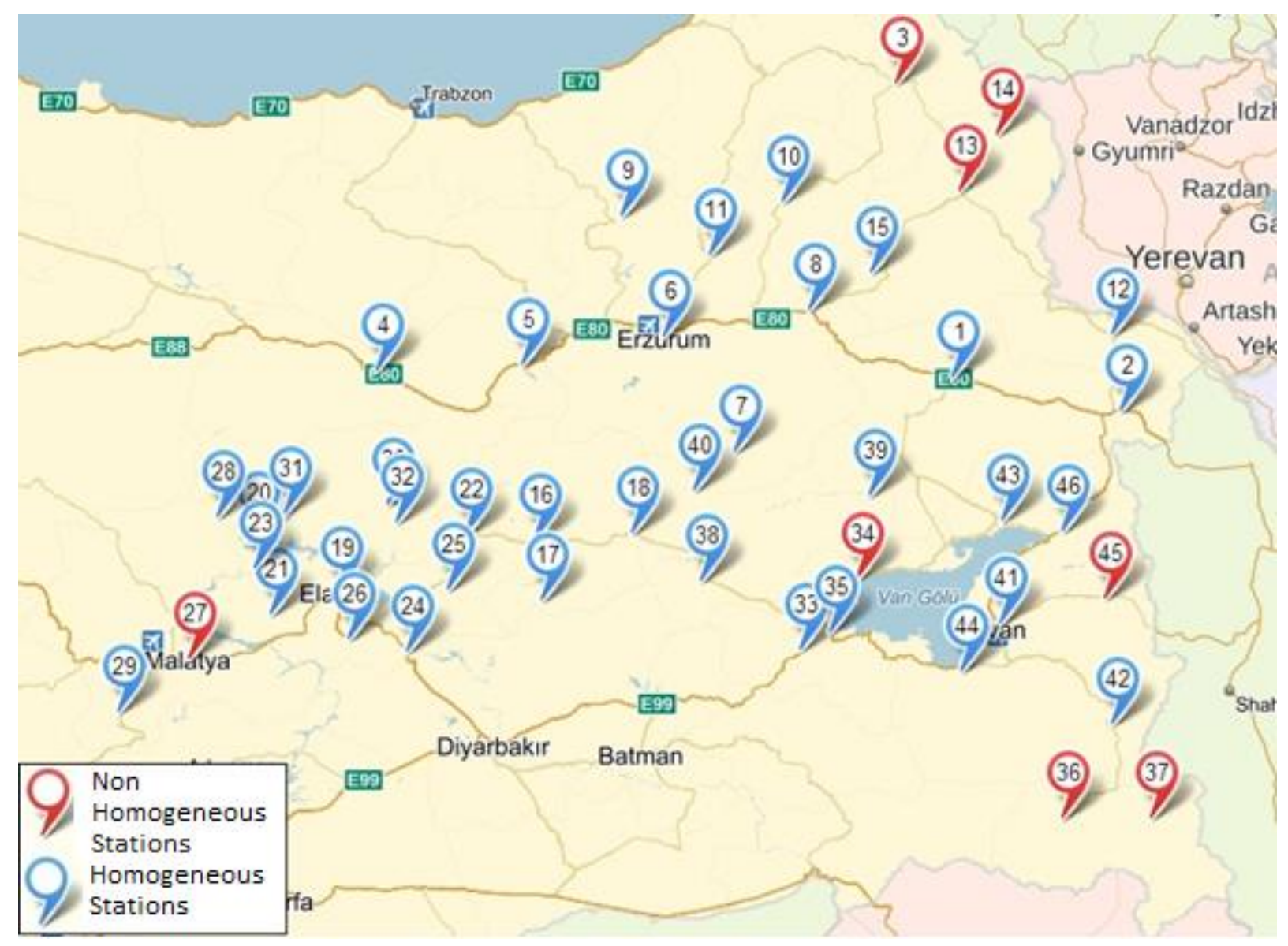

Figure 2.1. Locations of totally 46 rainfall measurement stations.

\subsection{Homogeneity}

The methods used to determine the trend of a series are collected under two headings; parametric and non-parametric methods, depending on whether the series is tied to a distribution or not (Hirsch 1992).

In parametrical methods, the real value of the data in the series is important and this value is used in the calculations. It is known that non-parametric methods give effective results compared to parametrical methods without the necessity of complying with normal distribution (Hirsch 1992). The Run (Swed Sw Eisenhart) and Pettitt test methods were preferred to determine the homogeneity of the series.

\subsubsection{Swed- Eisenhart run test}

The Swed and Eisenhart (Swed and Eisenhart 1943) run test is a non-parametric procedure used in determining the homogeneity of a time series. In general, it can adequately detect non-homogeneities as well as other problems such as a change of instrument, relocation of stations, etc. However, after detection of the non-homogeneity, further detailed physical and/or meteorological studies are needed in order to identify its major cause.

The test procedure depends on the truncation of the analyzed time series at the median level, giving rise to data values greater or smaller than the median. Any uninterrupted sequence of greater (or smaller) values preceded and succeeded by at least one smaller (or greater) value is referred to as a run. A succession of greater (or smaller) values constitutes a positive (or negative) run. In general, the number of positive runs is equal to negative runs plus or minus 1 . For the analyzed time series to be homogeneous, the number of positive (or negative) runs should be confined within the upper and lower confidence limits at a given significance level (usually 5 or 10 percent). The calculation of confidence limits is based on the assumption of a normal distribution. According to this test, if the number of runs falls between confidence limits than the data set considered is homogeneous (Thorn 1966).

\subsubsection{Pettitt test}

The Pettitt Test is a nonparametric test that does not require any assumptions about the distribution of data.This nonparametric method developed by Pettit (1979) to determine the point of change in a time series can find the point of change on a monthly or annual scales. While the null hypothesis indicates an independent and random distribution of the series, the alternative hypothesis indicates a sudden change. The test statistic is associated with the Mann - Whitney statistic. The critical values of this test are given below.

$\mathrm{Y}_{1}, \mathrm{Y}_{2}, \mathrm{Y}_{3}, \ldots, \mathrm{Y}_{\mathrm{n}}$ values are sequenced as $\mathrm{r}_{1}, \mathrm{r}_{2}, \mathrm{r}_{3}, \ldots, \mathrm{r}_{\mathrm{n}}$ 


$$
X_{k}=2 \sum_{i=1}^{k} r_{1}-k(n+1) \quad k=1,2, \ldots, n
$$

$\mathrm{X}_{\mathrm{k}}$ values are drawn as graphics. The absolute maximum value of $\mathrm{X}_{\mathrm{k}}$ determines the point of change.

$X_{E}=\max _{1 \leq k \leq n}\left|X_{k}\right|$

\subsection{Trend}

The trend that can be defined as long-term movement is the development or tendency of a time series in a long-term and a certain direction. Since trend analysis is a long-term analysis, the fact that the data is given monthly or seasonal does not affect the result of the analysis. The trend of a series can be linear or curvilinear. However, an important feature of the trend is stable in both cases (Köksal 1998).

\subsubsection{Mann-Kendall test}

Mann-Kendall test is a statistical testing method that is commonly used in defining the trend in time series in hydrology and climatology fields and that is also suggested by World Meteorological Organization (WMO). Mann-Kendall test pulled its rank in trend analysis in several studies. Non-parametric tests are usually more robust compared with parametric ones, among which the MannKendall test is the most used in hydrology and climatology. Therefore, to detect any monotonic trends in the precipitation time series at all considered grid points, the Mann-Kendall test was used. This test consists of comparing each value of the time series with the remaining in a sequential order. The Mann-Kendall statistic $\mathrm{S}$ is given as:

$$
S=\sum_{k=1}^{n-1} \sum_{j=k+1}^{n} \operatorname{sgn}\left(x_{j}-x_{k}\right)
$$

The application of trend test is done to a time series $x i$ that is ranked from $i=1, \ldots, n-1$ and $x j$, which is ranked from $j=i+1, \ldots, n$. Each of the data point $x i$ is taken as a reference point which is compared with the rest of the data points xj so that,

$$
\operatorname{sgn}\left(x_{i}-x_{j}\right)=\left\{\begin{array}{r}
+1 \text { if }\left(x_{i}-x_{j}\right)>0 \\
0 \text { if }\left(x_{i}-x_{j}\right)=0 \\
-1 \text { if }\left(x_{i}-x_{j}\right)<0
\end{array}\right.
$$

It has been documented that when $\mathrm{n} \geq 8$, the statistic $\mathrm{S}$ is approximately normally distributed with the mean. $\mathrm{E}(\mathrm{S})=0$

The variance statistic is given as:

$$
\operatorname{Var}(S)=\frac{n \cdot(n-1) \cdot(2 n+5)}{18}
$$

The test statistics $\mathrm{Z}$ is computed as:

$$
Z= \begin{cases}\frac{S-1}{\sqrt{\operatorname{Var}(S)}}, & S>0 \\ 0 & S=0 \\ \frac{S+1}{\sqrt{\operatorname{Var}(S)}}, & S<0\end{cases}
$$

$Z$ here follows a standard normal distribution. A positive (negative) value of $Z$ signifies an upward (downward) trend. A significance level $\alpha$ is also utilized for testing either an upward or downward monotone trend (a two-tailed test). If $Z$ appears greater than $Z(\alpha / 2)$ where $\alpha$ depicts the significance level, then the trend is considered as significant.

\subsubsection{Spearman's Rho test}

A quick and simple test to determine whether correlation exists between two classifications of the same series of observations is the Spearman's rank correlations test. In this test, there is a significant trend only if the correlation between time steps and rainfall observations are found to be significant. Account of the test statistic $\mathrm{Z}$ based on rs was not presented here, since it can easily be found in statistical books. The test statistics rs is computed as:

$$
r_{s}=1-6\left[\sum_{i=1}^{n}\left(R\left(x_{i}\right)-i\right)^{2}\right] /\left(n^{3}-n\right)
$$

For $\mathrm{n}>30$, the distribution of rs will be normal, so that the normal distribution tables can be used. In this case, the test statistic rs is computed by

$$
Z=r_{s} \sqrt{n-1}
$$


If $|Z|>Z \alpha$ at a significance level of $\alpha$; then the null hypothesis of no trend (on the other word, values of observations are identically distributed) is rejected.

\subsubsection{Sen's estimator of slope}

If a linear trend is present, the true slope (change per unit time) can be estimated by using a simple non-parametric procedure developed. In computational procedures, the slope estimates of $\mathrm{N}$ pairs of data are first computed by

$$
Q_{i}=\frac{x_{j}-x_{k}}{j-k}
$$

for $i=1, \ldots, N$; where $x j$ and $x k$ are data values at times $j$ and $k(j>k)$; respectively. The median of these N values of Qi is Sen's estimator of slope. If there is only one datum in each time period, then

$$
N=n(n-1) / 2
$$

where $\mathrm{n}$ is the number of time periods. If $\mathrm{N}$ is odd, then Sen's estimator is computed by

$$
Q_{\text {median }}=Q_{(N+1) / 2}
$$

and if is even, then Sen's estimator is computed by

$$
Q_{\text {median }}=\left[Q_{N / 2}+Q_{(N+2) / 2}\right] / 2
$$

The detected value of Qmedian is tested by a two-sided test at the 100(1- $\alpha) \%$ confidence interval and true slope may be obtained by the non-parametric test.

\section{Results}

Missing monthly rainfall data obtained from the General Directorate of Meteorology were estimated and homogeneity of all data together with missing ones were analysed for their homogeneity.

The trend analyses and slopes of the data were determined being obtained from the stations determined to be homogeneous. In the evaluations, monthly rainfall data in Eastern Anatolia Region were taken into consideration using non-parametric methods, MannKendall test and Spearman's rho test individually and together. Trend slopes of the stations were determined through Sen's slope method.

The findings obtained were explained on monthly and station bases.

\subsection{Homogeneity analysis}

As the result of the homogeneity analysis performed by both methods, totally 8 rainfall measurement stations were excluded from the study; one (Hakkari Rainfall Measurement Station) through the Run (Swed - Eisenhart) Test and seven through the Pettitt Test namely the Rainfall Measurement Stations of Ahlat, Ardahan, Arpaçay, Kars, Malatya, Özalp and Yüksekova since the data from these stations were not homogenous. Thus, data from 38 rainfall observation stations were evaluated in the trend study.

\subsection{Monthly Trend Analysis}

While performing monthly trend analysis, the monthly total rainfall data collected from the stations is analyzed in a way that will be evaluated within the month. Monthly precipitation data corresponds to the same number of data used in the trend analysis of the annual total precipitation data. Monthly rainfall data corresponds to the same number of data used in the trend analysis of the annual total precipitation data. It starts and ends in the same year. In the monthly trend analysis, Mann - Kendall test and Spearman's rho test were used with $90 \%$ and $95 \%$ confidence interval.

\subsubsection{Trend analysis of monthly rainfall with Mann-Kendall test}

The results of the analysis conducted through Mann-Kendall test over monthly rainfall at $95 \%$ and $90 \%$ confidence intervals are given in Table 3.1. The results are also shown in Figure 3.1. 
European Journal of Science and Technology

Table 3.1. Mann-Kendall test results for $10 \%$ and $5 \%$ level of significance

\begin{tabular}{|c|c|c|}
\hline Month & Increasing trend & Decreasing Trend \\
\hline January & Mazgirt* & - \\
\hline February & - & Ağr1, Erzurum \\
\hline March & Doğubeyazit* & Arapgir, Elaziğ $\breve{g}^{*}$, Keban \\
\hline April & Doğubeyazıt, Oltu* & Bingöl \\
\hline May & - & Gevaş, Karakoçan, Sivrice, Tercan $^{+}$ \\
\hline June & - & Ağın, Erciş*, Erzincan, Mazgirt ${ }^{+}$ \\
\hline July & Başkale*, Elazığ, Erciş, İspir*, Oltu & - \\
\hline August & Hinıs, Muş & - \\
\hline September & Ağın*, Çemişgezek*, Tunceli, Van, Varto* & - \\
\hline October & - & Erciş, Gevaş \\
\hline November & - & Ağın, Genç*, Tunceli*, Solhan ${ }^{+}$ \\
\hline December & - & İspir, Palu*, Solhan* \\
\hline
\end{tabular}

* Significant at both 5 and 10 per cent levels , + Significant at only 5 per cent levels

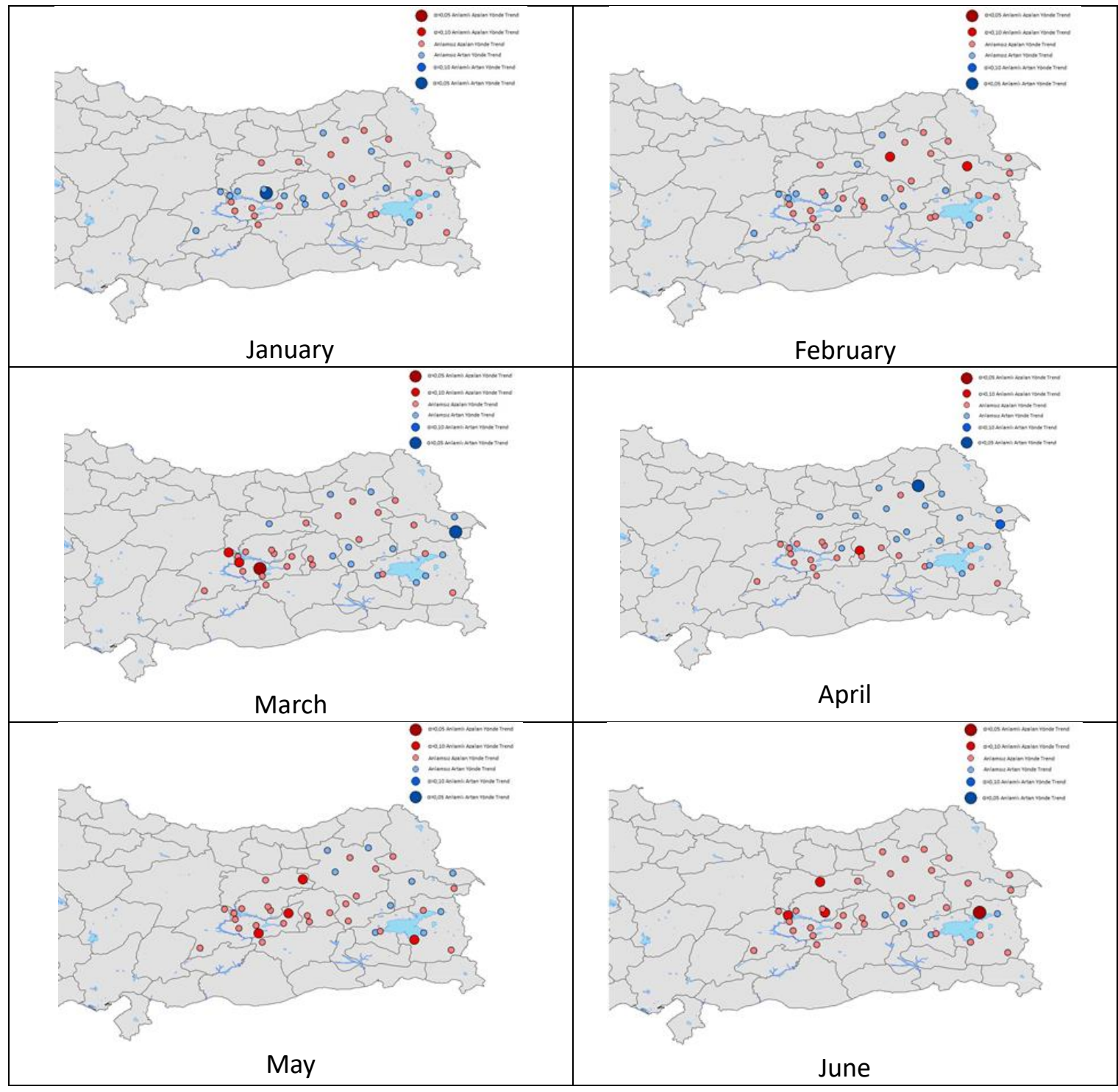




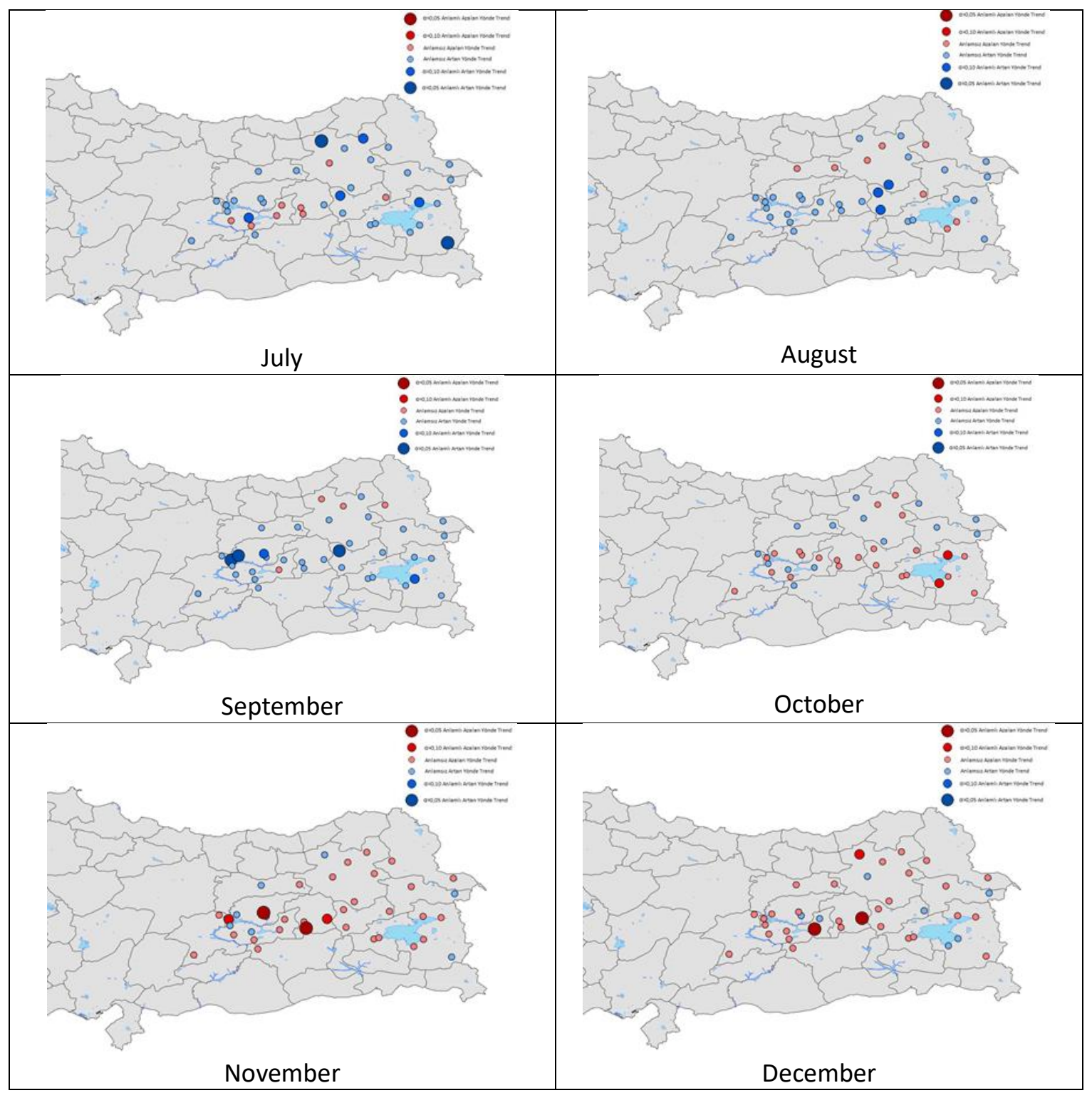

Figure 3.1. Mann-Kendall test results for $10 \%$ and $5 \%$ level of significance

\subsubsection{Trend analysis of monthly rainfall with Spearman's rho test}

Spearman's rho test method was used to perform trend analysis of monthly rainfall at $95 \%$ and $90 \%$ confidence intervals are given in Table 3.2. The results are also shown in Figure 3.2. 
European Journal of Science and Technology

Table 3.2. Spearman's rho test results for $10 \%$ and $5 \%$ level of significance

\begin{tabular}{|c|c|c|}
\hline Month & Increasing trend & Decreasing Trend \\
\hline January & Mazgirt* & Ağr1 \\
\hline February & Doğanşehir & Ağr1, Erzurum \\
\hline March & Doğubeyazıt* & Arapgir, Elazı $\breve{g}^{*}$, Keban \\
\hline April & Doğubeyazıt, Oltu* & - \\
\hline May & - & Gevaş, Karakoçan, Keban \\
\hline June & - & Ağın, Erciş*, Erzincan, Mazgirt \\
\hline July & $\begin{array}{l}\text { Başkale*, Çemiş̧gezek, Doğanşehir* Elazığ*, } \\
\text { Erciş*, İspir*, Keban*, Maden, Oltu, Tatvan, } \\
\text { Tunceli*, Varto }\end{array}$ & 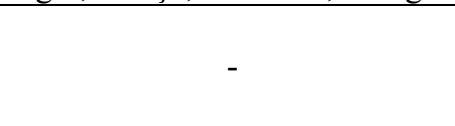 \\
\hline August & $\begin{array}{c}\text { Ağın*, Baskil, Bingöl*, Çemişgezek*, } \\
\text { Doğanşehir*, Elazı̆̆*, Genç, Hınıs, } \\
\text { Karakoçan*, Keban*, Maden*, Mazgirt*, } \\
\text { Muš, Palu*, Sivrice*, Tatvan, Tunceli*, Varto* }\end{array}$ & - \\
\hline September & $\begin{array}{l}\text { Ağın*, Baskil*, Çemişgezek*, Horasan, Maden, } \\
\text { Muradiye, Tunceli, Van*, Varto* }\end{array}$ & - \\
\hline October & - & Erciş \\
\hline November & - & $\begin{array}{l}\text { Ağın, Genç*, Maden, Solhan, } \\
\text { Tatvan, Tunceli }\end{array}$ \\
\hline December & - & İspir, Palu*, Solhan*, Tercan \\
\hline
\end{tabular}

* Significant at both 5 and 10 per cent levels , + Significant at only 5 per cent levels

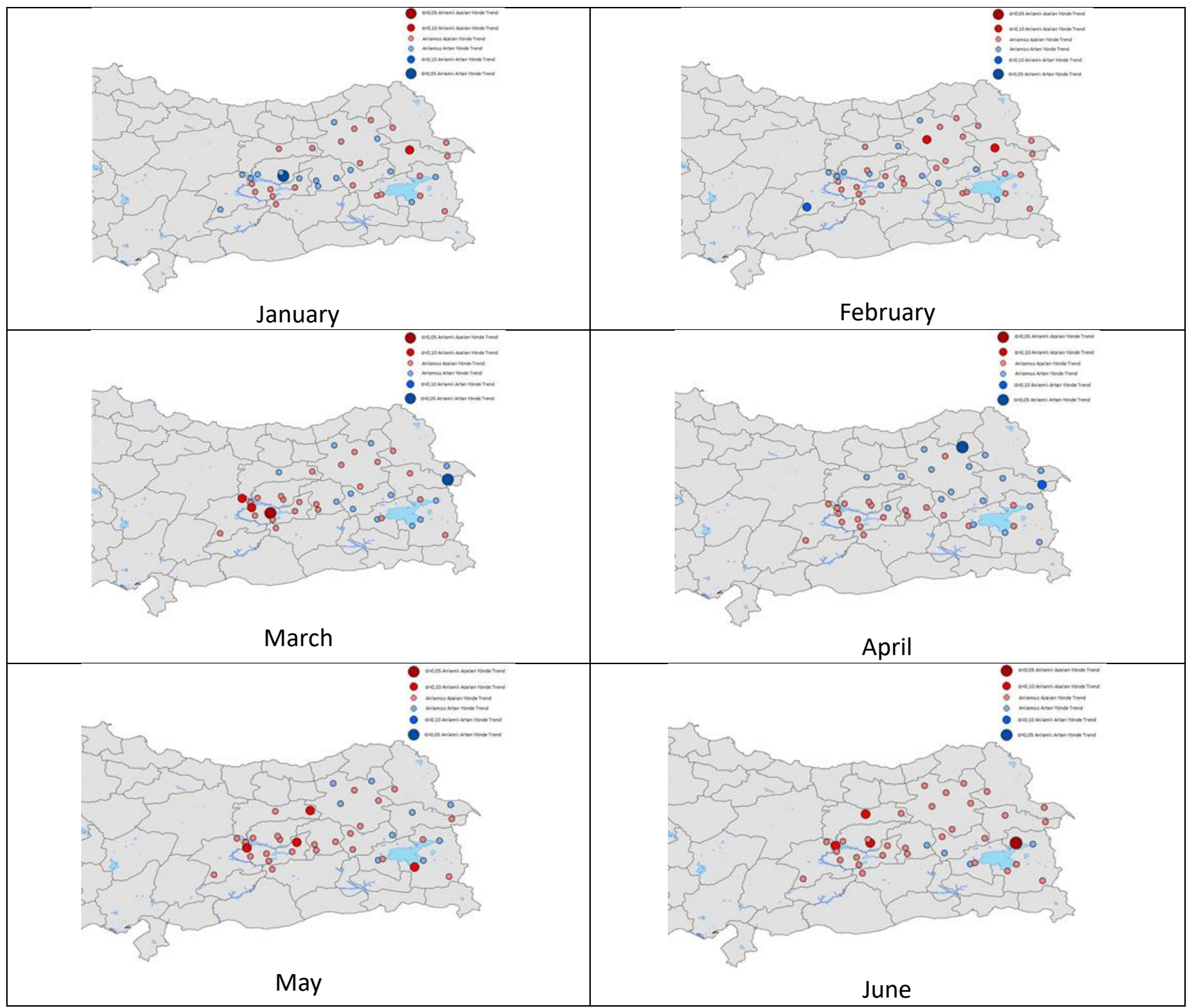




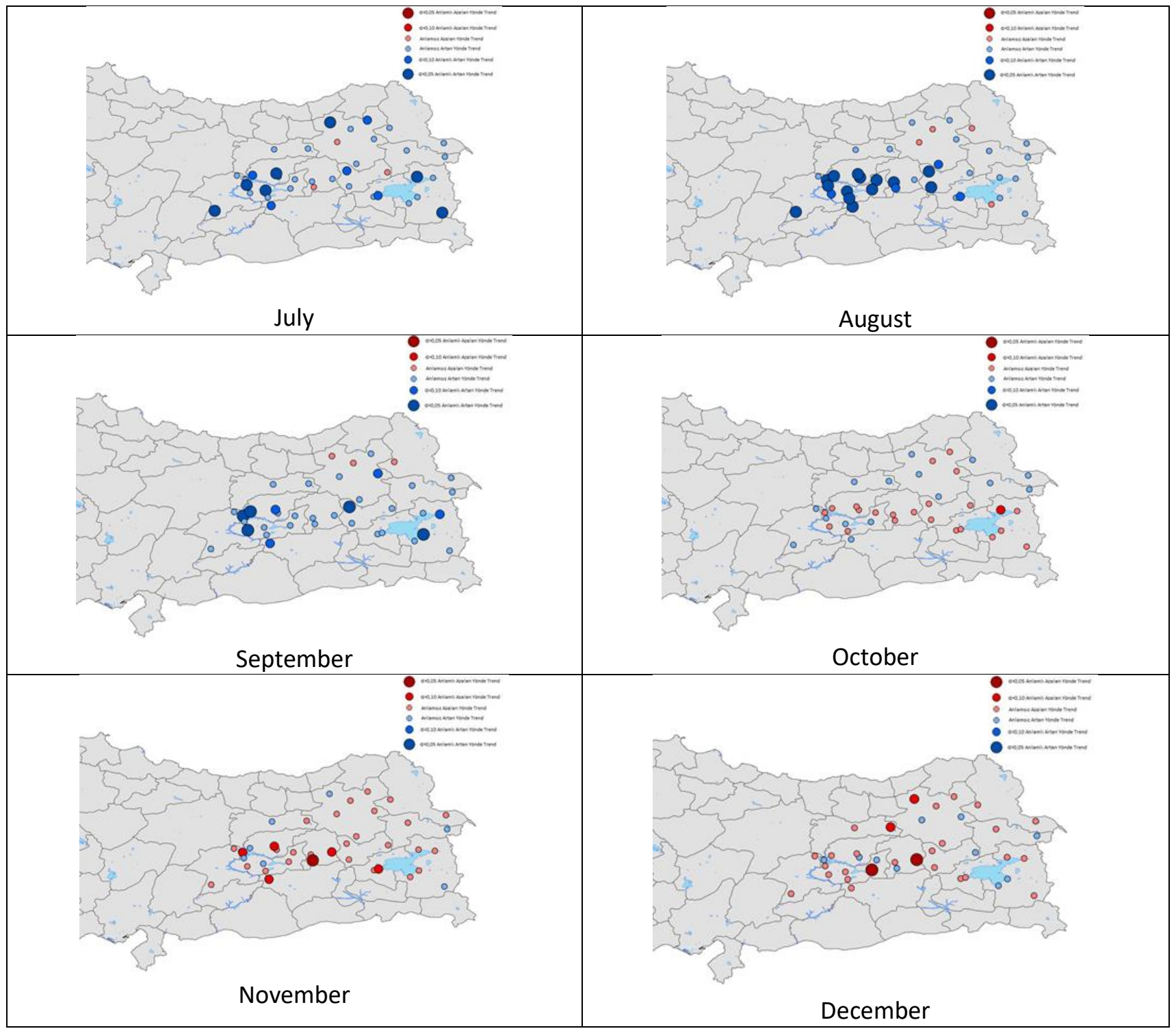

Figure 3.2. Spearman's rho test results for $10 \%$ and $5 \%$ level of significance

\subsubsection{The slope of monthly total precipitation with Sen's slope method}

The slopes of the monthly rainfall data at 38 rainfall measurement stations were estimated using Sen's slope method and the results are given in Table 3.3. The results are also shown in Figure 3.3. 
Table 3.3. Sen's slope results

\begin{tabular}{|c|c|c|c|c|c|c|c|c|c|c|c|c|}
\hline Station & Jan. & Feb. & Mar. & Apr. & May & June & July & Aug. & Sept. & Oct. & Nov. & Dec. \\
\hline Ağn1 & $-0,34$ & $-0,37$ & $-0,27$ & 0,32 & 0,30 & $-0,04$ & 0,05 & 0,03 & 0,11 & 0,09 & $-0,17$ & $-0,22$ \\
\hline Doğubeyazıt & $-0,02$ & $-0,02$ & 0,29 & 0,51 & $-0,13$ & $-0,27$ & 0,24 & 0,05 & 0,05 & 0,07 & 0,19 & 0,10 \\
\hline Erzincan & $-0,06$ & $-0,08$ & 0,11 & 0,16 & $-0,28$ & $-0,22$ & 0,03 & 0,00 & 0,12 & 0,05 & 0,09 & $-0,21$ \\
\hline Tercan & $-0,16$ & 0,00 & $-0,23$ & 0,18 & $-0,53$ & $-0,12$ & 0,13 & 0,00 & 0,07 & 0,28 & $-0,25$ & $-0,33$ \\
\hline Erzurum & $-0,12$ & $-0,21$ & $-0,06$ & 0,32 & 0,12 & $-0,35$ & $-0,10$ & $-0,04$ & 0,07 & 0,38 & $-0,14$ & 0,03 \\
\hline Hinıs & $-0,06$ & $-0,07$ & $-0,20$ & 0,31 & $-0,19$ & $-0,14$ & 0,10 & 0,10 & 0,09 & 0,12 & $-0,29$ & $-0,08$ \\
\hline Horasan & 0,07 & $-0,19$ & $-0,02$ & 0,42 & $-0,29$ & $-0,15$ & 0,33 & 0,17 & 0,22 & $-0,07$ & $-0,23$ & $-0,01$ \\
\hline İspir & 0,06 & 0,08 & 0,24 & 0,26 & 0,07 & $-0,11$ & 0,43 & 0,03 & $-0,08$ & 0,46 & 0,15 & $-0,42$ \\
\hline Oltu & $-0,14$ & $-0,05$ & 0,23 & 0,46 & 0,09 & $-0,18$ & 0,40 & 0,05 & 0,12 & $-0,04$ & $-0,20$ & $-0,17$ \\
\hline Tortum & $-0,12$ & $-0,16$ & $-0,15$ & $-0,05$ & $-0,17$ & $-0,38$ & 0,30 & $-0,07$ & $-0,07$ & $-0,07$ & $-0,26$ & $-0,23$ \\
\hline Iğdır & $-0,01$ & $-0,08$ & 0,06 & 0,28 & 0,24 & $-0,02$ & 0,07 & 0,03 & 0,02 & 0,02 & $-0,04$ & $-0,06$ \\
\hline Sarıkamış & $-0,07$ & $-0,31$ & $-0,17$ & 0,21 & $-0,36$ & $-0,53$ & 0,16 & $-0,11$ & $-0,07$ & 0,14 & $-0,31$ & $-0,32$ \\
\hline Bingöl & 0,00 & $-0,16$ & $-0,32$ & $-0,96$ & $-0,17$ & $-0,04$ & 0,00 & 0,00 & 0,02 & $-0,15$ & $-0,47$ & $-0,34$ \\
\hline Genç & 0,81 & $-0,72$ & $-1,28$ & $-0,64$ & $-0,95$ & $-0,30$ & $-0,03$ & 0,00 & 0,08 & $-0,80$ & $-2,16$ & $-0,07$ \\
\hline Solhan & 0,25 & 0,42 & 0,35 & $-0,55$ & $-0,09$ & 0,11 & 0,01 & 0,00 & 0,08 & $-0,31$ & $-0,87$ & $-1,06$ \\
\hline Elazığ & $-0,23$ & $-0,19$ & $-0,64$ & $-0,31$ & $-0,22$ & $-0,04$ & 0,00 & 0,00 & 0,04 & 0,14 & 0,04 & $-0,33$ \\
\hline Ağın & 0,12 & 0,07 & $-0,07$ & $-0,35$ & $-0,49$ & $-0,45$ & 0,00 & 0,00 & 0,14 & $-0,43$ & $-1,34$ & $-0,01$ \\
\hline Baskil & $-0,29$ & $-0,15$ & $-0,54$ & $-0,21$ & $-0,62$ & $-0,16$ & 0,00 & 0,00 & 0,10 & $-0,22$ & $-0,67$ & $-0,15$ \\
\hline Karakoçan & 0,38 & $-0,46$ & $-0,13$ & 0,74 & $-1,56$ & $-0,11$ & 0,00 & 0,00 & 0,20 & $-0,19$ & $-1,00$ & 0,15 \\
\hline Keban & $-0,20$ & $-0,21$ & $-0,46$ & $-0,40$ & $-0,49$ & $-0,16$ & 0,00 & 0,00 & 0,01 & 0,10 & 0,10 & $-0,15$ \\
\hline Maden & $-0,32$ & $-1,80$ & $-1,20$ & $-0,87$ & $-0,77$ & $-0,16$ & 0,00 & 0,00 & 0,06 & 0,72 & $-1,59$ & $-1,31$ \\
\hline Palu & $-0,37$ & 0,15 & $-0,22$ & $-0,10$ & $-0,46$ & $-0,05$ & 0,00 & 0,00 & 0,00 & 0,17 & $-0,63$ & $-0,71$ \\
\hline Sivrice & $-0,26$ & $-1,01$ & $-0,63$ & $-0,75$ & $-0,90$ & $-0,27$ & 0,00 & 0,00 & 0,10 & $-0,24$ & $-0,56$ & $-1,24$ \\
\hline Arapgir & 0,11 & 0,05 & $-0,93$ & $-0,67$ & $-0,05$ & $-0,10$ & 0,00 & 0,00 & 0,07 & 0,32 & $-0,35$ & $-0,69$ \\
\hline Doğanşehir & 0,14 & 0,48 & $-0,58$ & $-0,64$ & $-0,50$ & $-0,07$ & 0,00 & 0,00 & 0,04 & $-0,26$ & $-0,36$ & $-0,48$ \\
\hline Tunceli & 0,60 & $-0,11$ & $-0,99$ & $-0,59$ & $-0,49$ & $-0,10$ & 0,00 & 0,00 & 0,13 & $-0,06$ & $-1,19$ & $-1,35$ \\
\hline Çemişgezek & 0,12 & 0,10 & $-0,78$ & $-0,65$ & $-0,06$ & $-0,16$ & 0,00 & 0,00 & 0,08 & $-0,18$ & 0,24 & $-0,32$ \\
\hline Mazgirt & 1,68 & 0,53 & $-0,16$ & $-0,32$ & $-0,84$ & $-0,41$ & 0,00 & 0,00 & 0,13 & $-1,01$ & $-2,00$ & 0,46 \\
\hline Bitlis & $-1,15$ & $-0,66$ & 0,27 & $-1,08$ & 0,02 & 0,14 & 0,02 & 0,00 & 0,08 & $-0,83$ & $-0,12$ & $-0,94$ \\
\hline Tatvan & $-0,56$ & $-0,48$ & $-0,08$ & 0,46 & $-0,07$ & $-0,09$ & 0,07 & 0,00 & 0,03 & $-0,63$ & $-1,04$ & $-0,64$ \\
\hline Muș & $-0,19$ & 0,11 & 0,15 & $-0,30$ & $-0,08$ & 0,02 & 0,01 & 0,01 & 0,00 & $-0,36$ & $-0,74$ & $-0,54$ \\
\hline Malazgirt & 0,09 & 0,05 & 0,19 & 0,52 & 0,03 & $-0,17$ & $-0,02$ & 0,00 & 0,05 & $-0,32$ & $-0,08$ & 0,07 \\
\hline Varto & 0,01 & $-0,36$ & 0,48 & 0,09 & $-0,32$ & $-0,25$ & 0,28 & 0,20 & 0,33 & 0,01 & $-1,11$ & $-0,15$ \\
\hline Van & $-0,01$ & $-0,08$ & 0,13 & $-0,27$ & 0,09 & $-0,04$ & 0,01 & 0,00 & 0,00 & $-0,10$ & $-0,16$ & 0,18 \\
\hline Başkale & $-0,05$ & $-0,07$ & $-0,25$ & 0,00 & $-0,23$ & $-0,12$ & 0,25 & 0,01 & 0,00 & $-0,47$ & 0,12 & $-0,21$ \\
\hline Erciş & $-0,02$ & $-0,15$ & $-0,05$ & $-0,17$ & $-0,37$ & $-0,46$ & 0,12 & 0,00 & 0,02 & $-0,62$ & $-0,57$ & $-0,36$ \\
\hline Gevaş & 0,61 & 0,03 & 0,11 & 0,16 & $-1,19$ & $-0,18$ & 0,14 & 0,00 & 0,14 & $-0,96$ & $-1,05$ & 0,08 \\
\hline Muradiye & 0,21 & $-0,02$ & 0,42 & 0,23 & 0,07 & 0,11 & 0,19 & 0,00 & 0,12 & $-0,18$ & $-0,03$ & $-0,07$ \\
\hline
\end{tabular}

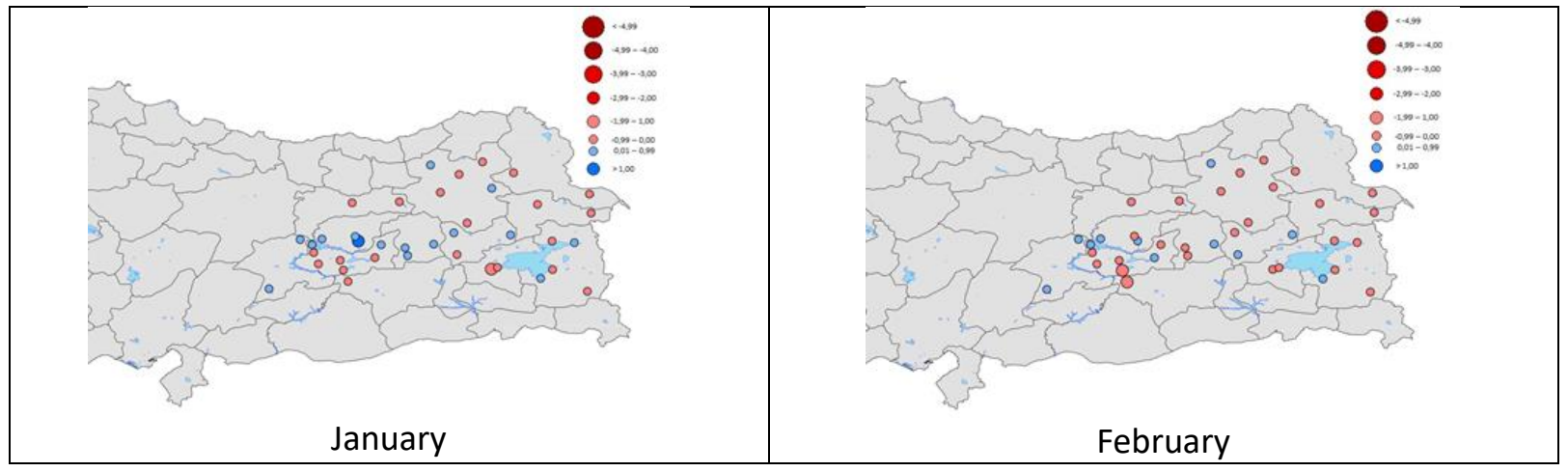




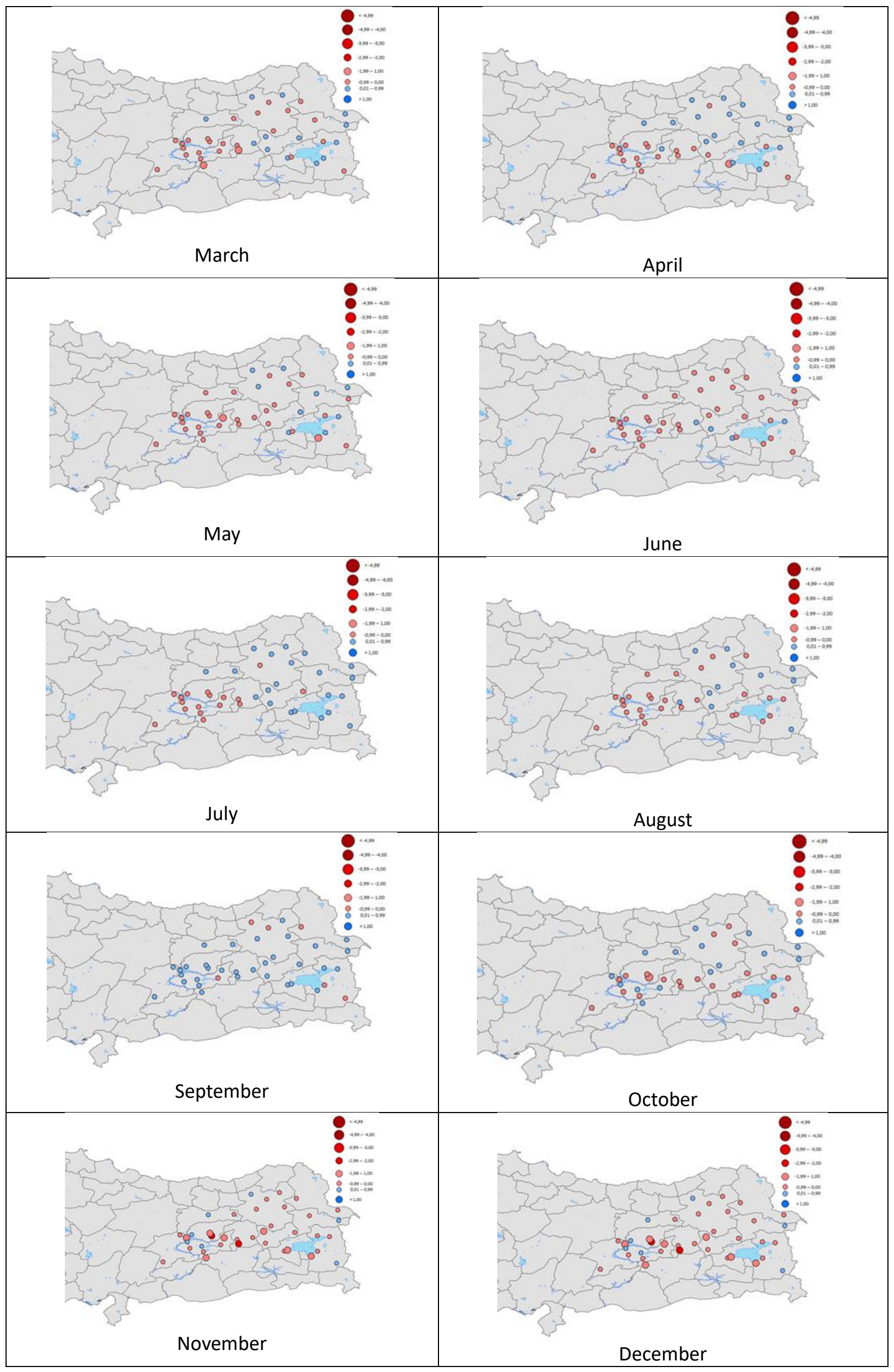

Figure 3.3. Monthly Sen's slope results 


\section{Conclusion}

Rainfall is the most important environmental factor that determines the structural characteristics, species diversity and vital rhythm of the animal and plant communities on earth as it is the source of the water required for their living. Monitoring the expected or observed changes in precipitation regime and rainfall is especially important for the regions where the drought constitutes a threat.

In Eastern Anatolia, the largest geographical region of Turkey in surface area, precipitations are generally in the form of snow and uneven; therefore, the flow regime is also irregular. Since the precipitations are is usually in snow form, in especially spring months, stream flows are rapid and strong. In addition, high elevations and slopes in the region also increase the hydroelectric potential.

In this study, the data obtained from the General Directorate of Meteorology were evaluated on monthly basis. As the result of the evaluation, it was observed that the largest rainfall was measured in April while the lowest was in August. The highest rainfall based on stations was observed in Bitlis station with $586.5 \mathrm{~mm}$ in February 1992 while the lowest (no rainfall) was measured in several stations in many months.

Two different methods were used to test the homogeneity of the data; Run test and Pettitt test. As a result of homogeneity analysis with Run test, it was determined that only Hakkari station was not homogeneous in $95 \%$ confidence interval. When the homogeneity analysis was performed by Pettitt test, it was determined that 7 rainfall stations, Ahlat, Ardahan, Arpaçay, Kars, Malatya, Özalp and Yüksekova, were not homogeneous in the $95 \%$ confidence interval.

Thus, among a total of 46 rainfall measurement stations, eight with non-homogeneous rainfall data were excluded from the study and 38 rainfall measurement stations were analyzed for trend analysis.

Mann - Kendall and Spearman's rho tests and Sen's inclination method were used for trend analysis of monthly total precipitation.

According to the common results of both of the trend analyses (at $90 \%$ confidence interval) which were conducted using Mann Kendall test and Spearman's rho test and evaluated in the $90 \%$ and $95 \%$ confidence intervals, a significant decrease was observed at the rainfall measurement stations of Ağın in June and November, Ağr in February, Arapgir in March, Elazığ in March, Erciş in June and October, Erzincan in June, Erzurum in February, Genç in November, Gevaş in May, Karakoçan in May, Keban in March, Mazgirt in June, Solhan in November and December and Tercan in May, while a significant increase was found for the stations of Tunceli in September and November, Ağın in September, Başkale in September, Çemişgezek in September, Doğubeyazıt in March and April, Elazığ in July, Erciş in July, Hınıs in August, İspir in July, Mazgirt in January, Muş in August, Oltu in April and July, Van in September, Varto in July, August and September.

In the $95 \%$ confidence interval, a significant increase was seen for the Rainfall Measurement Stations of Ağın in September, Başkale in July, Çemişgezek in September, Doğubeyazıt in March, Ispir in July, Mazgirt in January, Oltu in April, Varto in September while significant decrease was seen in Elazı ğ (March), Ercis (June), Genç, (November) and Solhan in December.

It may be stated when evaluated at $95 \%$ confidence interval according to Sen's slope method that the results generally show similarities between the trends found in both Mann - Kendall test and Spearman's rho test; however, in July and August, the results were found to be closer to those found in the Mann - Kendall test method.

When the trend analysis was conducted at 38 rainfall measurement stations using the Mann Kendall test and the Spearman's rho test, in both trend methods similar and differing results were obtained for monthly rainfalls. For some stations and months, there is a rising trend while a decreasing trend can be seen according to the other method. In a similar way, it is possible to see a trend in a decreasing direction at a station while it has an increasing characteristic in another method.

Analysing these differences seen in the trend analysis of the monthly rainfall using different trend methods in addition to the Mann - Kendall test and Spearman's rho test may give better results in terms of the accuracy of the results.

It is seen when the trend analysis of the monthly rainfall is evaluated that in summer months, rainfall is generally in an increasing trend while in winter its trend is in a decreasing direction. In June (summer), there is a declining trend in the region while in July the trend turns out to be an increasing way. In November, the trend is in decreasing direction again in the region.

In the present study, trend analysis was performed using only precipitation data. Conducting similar studies for other meteorological parameters may serve as a basis for both the reliability of the study and the studies on climate change. Likewise, evaluation of the present results considering different climate scenarios for the the region may also contribute to the determination of the water potential in the future in the region.

\section{References}

Acar, R. and S. Şenocak (2008). Detection of Statistically Significant Trends in The Short Duration Rainfalls (SDR) of Adana City, Turkey. EGU General Assembly 2008: IS22-HS2.1 Session on "Climate, Water and Health", Vienna, Austria.

Acar, R. and S. Şenocak (2012). Annual extreme precipitation trends for western Turkey in associated with North Atlantic Oscillation (NAO) index. Energy Education Science and Technology Part a-Energy Science and Research, 29(1), 475-486.

Büyükyıldız, M. (2004). Sakarya Havzası Yağışlarının Trend Analizi ve Stokastik Modellemesi. Fen Bil. Enst., İnşaat Mühendisliği Anabilim Dal, Doktora Tezi, Selçuk Üniversitesi.

Çiflik, D. (2012). Ege bölgesi DSİ istasyonlarında ölçülen yıllık toplam yağışların trend analizi. Fen Bil. Enst., Inşaat Mühendisliği Anabilim Dall, Y.Lisans Tezi, Ege Üniversitesi. 
Demir, İ., G. Kılıç and M. Coşkun (2007). Türkiye ve bölgesi için PRECIS bölgesel iklim modeli çalışmaları. İklim Değişikliği ve Çevre, $1(1), 11-17$.

Demirci, A., Karaburun A. and F. Kara (2009). Uzun Dönem Sicaklık Verilerinde Thiessen ve Mann Kendall Metodları ile Trend Analizlerinin Yapılması: İstanbul Örneği. 3. Ulusal DEÜ CBS Sетроzyuтu, 10-11.

Gautam, M. and K. Acharya (2012). Streamflow trends in Nepal. Hydrological sciences journal, 57(2), 344-357.

Gümüş, V. and K. Yenigün (2006). Aşağı Fırat Havzası akımlarının trend analizi ile değerlendirilmesi. Yedinci Uluslararası İnşaat Mühendisliğinde Gelişmeler Kongresi, 11-13.

Güventürk, A. (2013). Impacts of climate change on water resources eastern mountainous region of Turkey Master of Science, Middle East Technical University.

Han, J.-C., G.-H. Huang, H. Zhang, Z. Li and Y.-P. Li (2013). Heterogeneous precipitation and streamflow trends in the Xiangxi River watershed, 1961-2010. Journal of Hydrologic Engineering, 19(6), 1247-1258.

Hirsch, R. (1992). Statistical Methods in Water Resources. Studies in Environmental Science, Elsevier Science \& Technology.

Liu, D., S. Guo, X. Chen and Q. Shao (2012). Analysis of trends of annual and seasonal precipitation from 1956 to 2000 in Guangdong Province, China. Hydrological sciences journal, 57(2), 358-369.

Mondal, A., S. Kundu and A. Mukhopadhyay (2012). Rainfall trend analysis by Mann-Kendall test: A case study of north-eastern part of Cuttack district, Orissa. International Journal of Geology, Earth Environmental Sciences, 2(1), 70-78.

Norrant, C. and A. Douguédroit (2006). Monthly and daily precipitation trends in the Mediterranean (1950-2000). Theoretical Applied Climatology, 83(1-4), 89-106.

Öztürk, K. (2002). Küresel İklim Değişikliği ve Türkiyeye Olası Etkileri. Gazi Üniversitesi Gazi Eğitim Fakültesi Dergisi, 22(1).

Partal, T. and E. Kahya (2006). Trend analysis in Turkish precipitation data. Hydrological Processes: An International Journal, 20(9), 2011-2026.

Pettit, A. (1979). Anon-parametric approach to the change-point detection. Applied Stat., 28, 126-135.

Raziei, T., J. Daryabari, I. Bordi and L. S. Pereira (2014). Spatial patterns and temporal trends of precipitation in Iran. Theoretical applied climatology, 115(3-4), 531-540.

Serrano, A., V. Mateos and J. Garcia (1999). Trend analysis of monthly precipitation over the Iberian Peninsula for the period 19211995. Physics Chemistry of the Earth, Part B: Hydrology, Oceans Atmosphere, 24(1-2), 85-90.

Siddik, M. A. Z. and M. Rahman (2014). Trend analysis of maximum, minimum, and average temperatures in Bangladesh: 1961-2008. Theoretical applied climatology, 116(3-4), 721-730.

Swed, F. S. and C. Eisenhart (1943). Tables for testing randomness of grouping in a sequence of alternatives. The Annals of Mathematical Statistics, 14(1), 66-87.

Şen, C. (2013). Isparta ilinde sıcaklık ve yağış verilerinin trend analizi, SDÜ Sosyal Bilimler Enstitüsü, Y. Lisans Tezi, Isparta.

Talaee, P. H. (2014). Iranian rainfall series analysis by means of nonparametric tests. Theoretical applied climatology, 116(3-4), 597607.

Thorn, H. (1966). Some methods of climatological analysis. WMO technics/note, number(81), 16-22.

Türkeş, M. (1998). Influence of geopotential heights, cyclone frequency and southern oscillation on rainfall variations in Turkey. International Journal of Climatology: A Journal of the Royal Meteorological Society, 18(6), 649-680.

Türkeş, M. (1999). Vulnerability of Turkey to Desertification with Respect to Precipitation Andridity Condition, Tr. J. of Engineering and Environmental Science, 23, $363-380$.

Türkeş, M., K. Telat and F. Sarış (2007). Türkiye'nin Yağiş Toplami ve Yoğunluğu Dizilerindeki Değişikliklerin ve Eğilimlerin Zamansal ve Alansal Çözümlemesi. Coğrafi Bilimler Dergisi, 5(1), 57-73.

Uçgun, E. (2010). Kızılırmak havzası'ndaki hidrometeorolojik verilerin trend analizi. Fen Bil. Enst., Inşaat Mühendisliği Anabilim Dall, Doktora Tezi, Kırıkkale Üniversitesi. 